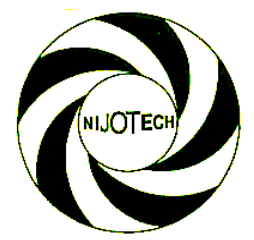

Nigerian Journal of Technology (NIJOTECH)

Vol. 38, No. 3, July 2019, pp. 792 - 797

Copyright@ Faculty of Engineering, University of Nigeria, Nsukka,

Print ISSN: 0331-8443, Electronic ISSN: 2467-8821 www.nijotech.com

http://dx.doi.org/10.4314/njt.v38i3.35

\title{
SPATIAL AND TEMPORAL VARIABILITY IN DISSOLVED OXYGEN CONTENT OF ASORO STREAM, IN SOUTH WESTERN NIGERIA
}

\author{
J. O. Jeje $\mathrm{e}^{1, *}$ and K. T. Oladepo ${ }^{2}$ \\ 1,2, Department of Civil Engineering, Obafemi Awolowo University, Ile-Ife, Osun StaTe, NIGERIA \\ E-mail addresses: ${ }^{1}$ jemails2000@yahoo.co.uk, ${ }^{2}$ cve403.oauife@gmail.com
}

\begin{abstract}
This study examined the spatial and temporal variation of dissolved oxygen (DO) concentration in Asoro stream, the self-recovery ability of the stream of the effluent discharges with a view to providing a baseline information on quality of water in Asoro stream. DO is a measure of the ability of water to sustain aquatic life, it is important in water pollution control and waste water treatment process control. Samples were collected from fifteen sampling points along the Asoro stream at 500 $m$ intervals over a 5000 m stretch for twelve-months. The DO, Biochemical Oxygen Demand and some other physico-chemical parameters of water were determined using standard methods. The hydrographic characteristics of the stream were; width $(0.8$ to $5.8 \mathrm{~m})$, depth $(0.1$ to $0.55 \mathrm{~m})$, discharge ( 0.30 to $0.52 \mathrm{~ms}^{-1}$ ), flow rate 0.07 to $0.0 .73 \mathrm{~m}^{3} / \mathrm{s}$. The temporal variation in DO concentration in Asoro stream fluctuated from the first week of sampling to 25th week after with a peak range of concentration $(7.46 \mathrm{mg} / \mathrm{L}$ to $10.12 \mathrm{mg} / \mathrm{L})$ between 27 th week and 39th week of sampling suggesting high level of organic pollution. The mean spatial distribution of DO at each station changed slightly between the point of brewery effluent discharge and $5000 \mathrm{~m}$ away. Regression analysis showed that there was no significant relationship ( $P \geq 0.05)$ between time (weeks) and DO concentration along Asoro stream. The study concluded that release of organic matter from industrial effluent affects the DO and BOD concentrations of Asoro stream.
\end{abstract}

Keywords: Dissolved oxygen, Temporal, Spatial, Asoro stream, self- recovery

\section{INTRODUCTION}

Asoro stream in Ilesa East Local Government Area, Osun state, Nigeriam is a major source of water to the communities in the area. However, the stream water is not suitable for municipal purposes being a receiver of polluted brewery effluent. There is dearth of information on hydrographic and physico-chemical characteristics of the stream water which will help in evaluating its quality for intended use. Dissolved oxygen (DO) concentration is a vital health indicator of stream ecosystems. Variation in DO may be affected by various physical, chemical, and biological processes and factors.

Rivers and streams are used for the disposal of municipal and industrial wastes, and Hull [1] was of the opinion that this is one of the most important factors contributing to the general health and welfare of the people.
Discharge of wastes into a stream, however, does not simply dilute the wastes. Each Stream and river has a natural capacity for oxidizing biodegradable waste, thus purifying the waters [2]. This purification capacity is dependent upon many factors, including the water discharge, the depth of flow, the velocity of flow, and the various sinks of dissolved oxygen along the stream.

The self-purification factor describes the unique measure of the ability of each surface water body to cleanse itself of whatever pollution that gets into it. While flowing surface water bodies get self-purified faster than slow moving or stagnant surface water bodies, a factor that contributes significantly to the rate of self-purification is temperature [3].

Sources and sinks of pollutants include waste loads, and the physical and biochemical processes that alter those waste loads. Aquatic pollution occurs when the

* Corresponding author, tel: +234-803-344- 7245 
self-purifying powers of water are unable to remove the materials added to it [4]. This inability could arise from the fact that the time was not long enough or that the load or organic matter was too heavy. The ability of water body to return to its original state over a period of time is known as self- purification capacity unlike flowing water bodies such as streams and rivers which gradually release some of the wastes along its course [5].

Water pollution has many causes and characteristics where increases in nutrients loading may lead to eutrophication. Organic wastes such as sewage impose high oxygen demand on the receiving water leading to oxygen depletion with potentially severe impacts on the whole ecosystem [6]. Industries discharge a variety of pollutants in their wastewater. Such pollutants include heavy metals, organic toxins, oil, nutrients and solids. Discharge can also have thermal effects especially those from power stations and these also reduce the available oxygen [7].

\section{METHODOLOGY}

Reconnaissance visit was made to the study area to determine the number of sampling points required for the study. A Digital display measuring wheel (DDMW) was used to accurately establish the distance between one sampling point to the other.

Fifteen sampling points were selected for this study, two points within the brewery and the remaining stations along the Asoro stream at $500 \mathrm{~m}$ intervals. Within the brewery, one sample was taken at the water inlet (influent) to the treatment plant and another at the exit of the treatment plant (effluent). Along the stream, one sample was taken at the point of discharge from the brewery outfall, three samples were taken upstream of this point and nine samples downstream of the point at two weeks intervals for twelve-months (November 2016 to October 2017). All sampling exercise were carried out within the hours of $7 \mathrm{am}$ and $11.00 \mathrm{am}$.

The average width and depth of the stream were determined at each sampling point. The average velocity was determined by using the float displacement method. The stream flow rate was determined. The temperature and $\mathrm{pH}$ were measured in-situ (on the field). At each sampling point, water samples were collected with Dissolved Oxygen (DO) and Biochemical Oxygen Demand (BOD) reagent bottles and with $1 \mathrm{~L}$ plastic bottle [10].

Spatial patterns of annual dissolved oxygen concentration in the Asoro stream was determined by finding the mean variation in DO at each sampling station from December 2016 to October 2017 which showed the trends in annual DO from the point of effluent discharge to the end of the selected distance of $5000 \mathrm{~m}$ [10].

\subsection{Temporal Variation of DO Concentration}

Analysis of DO variation was carried out over a period of 53 weeks, to show the pattern of variation over a period of time along Asoro stream. Regression analysis was applied to determine the relationship of two variables $B O D$ and flow rate $(Q)$, which determines relative direction. In this study, regression analysis was used to get the linear regression of DO and time in the following equation:

$$
\mathrm{DO}=\mathrm{at}+\mathrm{b}
$$

Where: DO is the dissolved oxygen $(\mathrm{mg} / \mathrm{L}), \mathrm{t}$ is the time (s), and $\mathrm{a}$ and $\mathrm{b}$ are the measured parameters (BOD and Q), thus changing trend of weekly concentration was determined.

\subsection{Description of the Study Area}

The study was carried out around the premises of a brewery and along the receiving stream of the brewery effluent in Osun State, Nigeria. The brewery is located in the South western part of Ilesa, Osun state on Latitudes $\left(007^{\circ}, 37^{\prime}\right.$ and $07^{\circ} 48^{\prime} \mathrm{N}$ and longitudes $007^{\circ}$ $40^{\prime} \mathrm{E}$ and $007^{\circ} 47^{\prime} \mathrm{E}$ (Figure 2.1). Portions of the stream can be sighted in communities such as EsaOke, Iloko-Ijesa and Erin-Ijesa. The segment which was selected for this study covers a distance of $500 \mathrm{~m}$. The brewery which started production in 1978 covers an area of about $4,600 \mathrm{~m}^{2}$ (0.46 ha) with an average effluent discharge of about $500 \mathrm{~m}^{3}$ per day. All effluents resulting from various processes (Mashing/brewing, fermentation, bottling/filling, finishing/packaging and cooling/storage) in the brewery used to be treated in two sedimentation tanks and a pair of oxidation ponds before a new treatment plant was commissioned in 2015.

The main materials used are effluents from the brewery and water samples taken along the stream at $500 \mathrm{~m}$ intervals. The inspection to the brewery was carried out to assess the effluent treatment facilities, effluent generation patterns and establish the sampling points. The equipment used for the research work are available in the Department of Civil Engineering, Obafemi Awolowo University, Ile-Ife. 


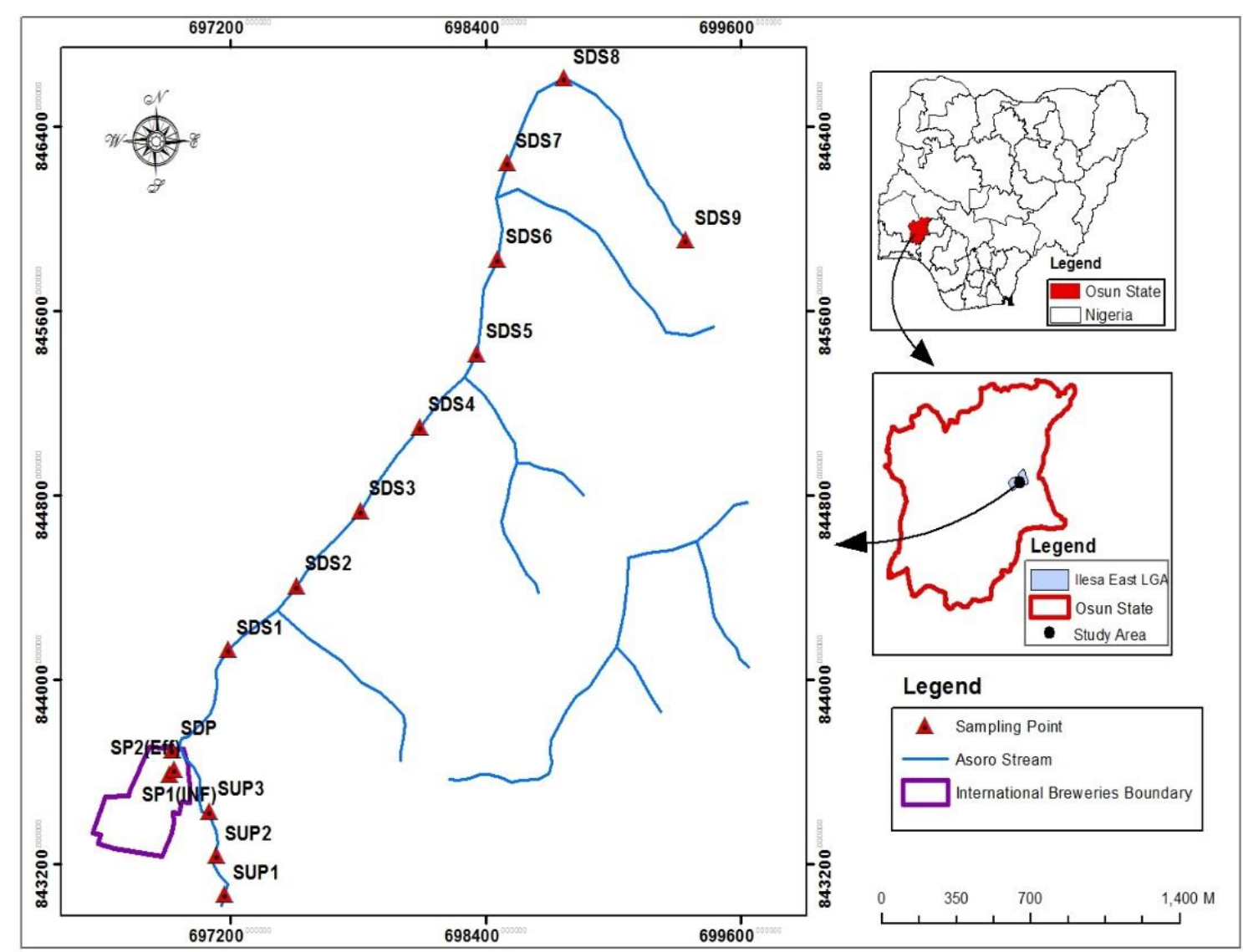

Figure 2.1: Map of the Study Area showing sampling points within the brewery and along the Asoro stream.

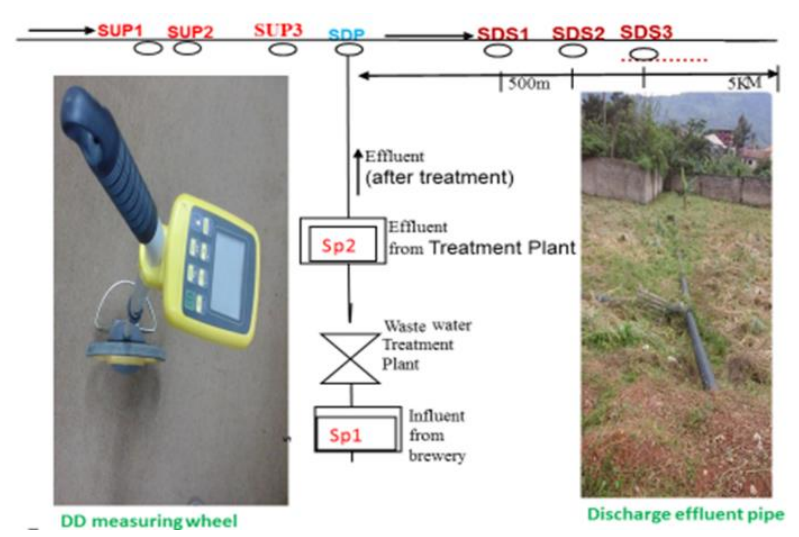

Figure 2.2: Linear representation of sampling points

The samples were collected into three different containers at each sampling station; the first sampling was carried out by dipping DO bottles into the stream and allow total exclusion of air bubbles and $2 \mathrm{ml}$ of $\mathrm{MnSO}_{4}$ and $\mathrm{KI} \mathrm{NaOH}$ were added in-situ to fix the DO. The first set of samples were collected in DO bottles for determination of DO, the second set of sampling was carried out by dipping the BOD bottle into the stream to completely fill the bottle while the last set of sampling was done by dipping a $1 \mathrm{~L}$ clean fresh plastic keg into the water bodies for grap sampling [8].
The third set were collected in one-litre plastic bottles for the determination of other parameters such as temperature, $\mathrm{pH}$, DO, suspended solids, Total Dissolved Solids (TDS), BOD, colour, turbidity and electrical conductivity.

The locations of the sampling points were determined using a Germin GPS Map 76 Positioning System. This was used to produce a digitised map given sample number. The Digital Display Measuring Wheel (DDMW) model EW31/8cy43 was used to measure and establish the sampling points before erection of sampling identification boards as shown in Figure 2.2. The $5000 \mathrm{~m}$ long stretch from upstream at Ilesa East to Adecom area was mapped with geographical positioning systems (GPS) and Digital Display Measuring Wheel (DDMW) and divided into 10 reaches with further segmentation of $500 \mathrm{~m}$ each from where DO, BOD and grab samples were collected routinely for twelve months. The $\mathrm{pH}$, TDS, electrical conductivity, temperature, width, depth and velocity were determined in-situ immediately after collection using a hand held $\mathrm{pH}$, TDS/EC instrument (Lovebay 3 in 1 Multifunctional water quality tester). Some parameters were determined in-situ such as width, depth, velocity, temperature, $\mathrm{pH}, \mathrm{TDS}$, and electrical 
conductivity. Other parameters such as dissolved oxygen (DO), biochemical oxygen demand (BOD) and turbidity were determined in the laboratory using appropriate analytical instruments.

\section{RESULTS AND DISCUSSION}

The physiognomies of the sampling points are summarized in Table 1; colour classification, n-values of the stream bed, stream bed materials, geographic coordinates and distance from the discharge point.

\subsection{Hydrographic Characteristics of the Stream} The mean ranges of widths, depths, velocities and the flow rate of the stream, measured at each sampling point of Asoro stream are shown in Figure 3.2.

\subsection{Spatial Variation of Dissolved Oxygen (DO) Concentration}

Spatial patterns of annual DO in the Asoro stream from December 2016 to October 2017 are shown in Figure 3.1. The mean annual DO at each station changed slightly between the point of effluent discharge and SDS9 (5000 $\mathrm{m}$ away from point of effluent discharge).
The slight drops in DO along the stream $(2.87 \mathrm{mg} / \mathrm{l}$, $3.65 \mathrm{mg} / \mathrm{l}$ and $3.57 \mathrm{mg} / \mathrm{l}$ observed at $1000 \mathrm{~m}, 1500 \mathrm{~m}$ and $2000 \mathrm{~m}$ respectively away from the discharge point might be due to ecological changes and drop in aeration rate [9]. Spatially, the DO along the stream increased $(4.03 \mathrm{mg} / \mathrm{l}-5.4 \mathrm{mg} / \mathrm{l})$ at $2500 \mathrm{~m}$ (SDS5) away of discharge to SDS 9 at $5000 \mathrm{~m}$ away from the discharge point of brewery effluent. The values obtained between $2500 \mathrm{~m}$ (SDS 5) and $5000 \mathrm{~m}$ (SDS 9) slightly exceeded the standard limit set by Federal Environmental Protection Agency in Nigeria. This problem is exacerbated when the purifying capacity of river systems is low in relation to the received contaminants.

The physical, chemical and biological processes that occur simultaneously, in the stream which allows a river to recover its natural state over a certain distance may have been responsible for these spatial variations in DO [10]. Also, the river continuum theory supported this pattern of variation, which may be caused by the river ecosystem that changes along the river as conditions changes [11].

Table 1: Physiognomies of the sampling stations

\begin{tabular}{lcccccc}
\hline $\begin{array}{l}\text { Sampling } \\
\text { Code }\end{array}$ & $\begin{array}{c}\text { Colour } \\
\text { classification }\end{array}$ & $\begin{array}{c}* \text { n-value } \\
\text { of stream } \\
\text { bed }\end{array}$ & $\begin{array}{c}\text { Streambed } \\
\text { materials }\end{array}$ & $\begin{array}{c}\text { Geographic Coordinates } \\
\text { Latitudes } \\
\text { Longitudes } \\
(\mathrm{N})\end{array}$ & $\begin{array}{c}\text { Dist from } \\
\text { point of } \\
\text { disch (m) }\end{array}$ \\
\hline INF & Brown & NA & NA & 0676282 & 6978524 & 600 \\
EFF & Black & NA & NA & 0676280 & 6978506 & 254 \\
SUP 1 & Light brown & 0.9 & Muddy & 0697185 & 0843054 & 1500 \\
SUP 2 & Light brown & 0.9 & Muddy & 0697162. & 0843023 & 1000 \\
SUP 3 & Black & 0.8 & Coarse/ & 843693.2 & 696930.2 & 500 \\
& & weedy & & & \\
SDP & Black & 0.9 & Sandy & 844236.0 & 697402.5 & 0 \\
SDS 1 & Black & 0.9 & Sandy & 844300.6 & 697501.5 & 500 \\
SDS 2 & Black & 0.8 & Coarse & 844394.1 & 697646.8 & 1000 \\
SDS 3 & Black & 0.8 & Coarse & 844560 & 697726.3 & 1500 \\
SDS 4 & Black & 0.8 & Coarse/ & 844620 & 699725.3 & 2000 \\
& & Weedy & & & \\
SDS 5 & Black & 0.8 & Coarse/ & 844688.4 & 688979.0 & 2500 \\
SDS 6 & Black & 0.8 & Weedy & & & \\
& & Coarse & 844769.1 & 697921.1 & 3000 \\
SDS 7 & Black & 0.9 & Muddy & 844809.0 & 697948.5 & 3500 \\
SDS 8 & Black & 0.9 & Muddy & 830593.7 & 668012.2 & 4000 \\
SDP 9 & Black & 0.9 & Sandy & 830627.2 & 668111.4 & 5000 \\
\hline
\end{tabular}

NOTE 1: INF = Influent from Brewery Industry, EFF= Effluent from treatment Plant, SUP = Samples Upstream, SDP $=$ Samples at Discharged Point, SDS = Samples Downstream

2: $\mathbf{n} *$-value take into consideration the roughness of the streambed in the calculation of corrected velocity 


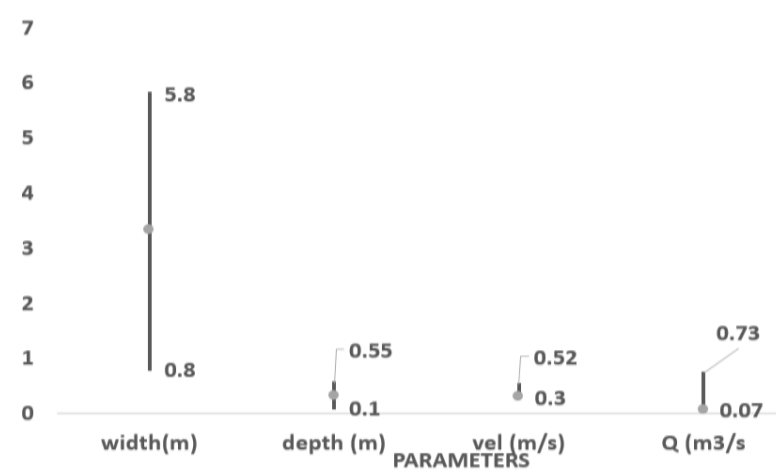

Figure 3.1: Hydrographic Charatristics of Asoro Stream

DO levels of surface water bodies normally drop after pollution discharges while their recovery depend on a number of intervening factors such as dilution factor and rate of reaeration process in the water bodies. Usually, the biodegradable wastes use up the DO content of the surface water in the recovery process. The pollution load in a river body could be measured in terms of BOD. The BOD value gives an indication of the level of DO required to break down a specific waste load and the higher the load, the higher the BOD value [3]..

BOD and distance correlated with $\mathrm{DO}$ at $\mathrm{P} \leq 0.01$ while TDS and EC correlated with $D O$ at $P \leq 0.05$. Out of four variables (BOD, TDS, EC and distance) subjected to multiple regression, only TDS and distance had significant relationship with DO which indicated that the TDS and the DO increased along the stream. The physical, chemical and biological processes that occur simultaneously, in the stream which allows a river to recover its natural state over a certain distance may have been responsible for these spatial variations in DO [10].

\subsection{Temporal Variation in Dissolved Oxygen (DO) Concentration}

Figure 3.2 shows temporal variation of dissolved oxygen concentrations along Asoro stream. The DO fluctuated (sinusoidal pattern) between $3.38 \mathrm{mg} / \mathrm{l}$ (Dec.) at the first week of sampling and $2.37 \mathrm{mg} / \mathrm{l}$ at 25th week (April) of sampling This fluctuations might be due to the dilution rate of the brewery effluent at that period [12]. High level of DO concentration (7.46 $\mathrm{mg} / \mathrm{l}$ to $10.12 \mathrm{mg} / \mathrm{l}$ ) was recorded between 27th week and 39th week of sampling (June and July) which showed low level of organic pollutant. The value of DO also fluctuated $(3.27 \mathrm{mg} / \mathrm{l}-2.61 \mathrm{mg} / \mathrm{l})$ at 41 st to $53 \mathrm{rd}$ week of sampling August - October). Time and

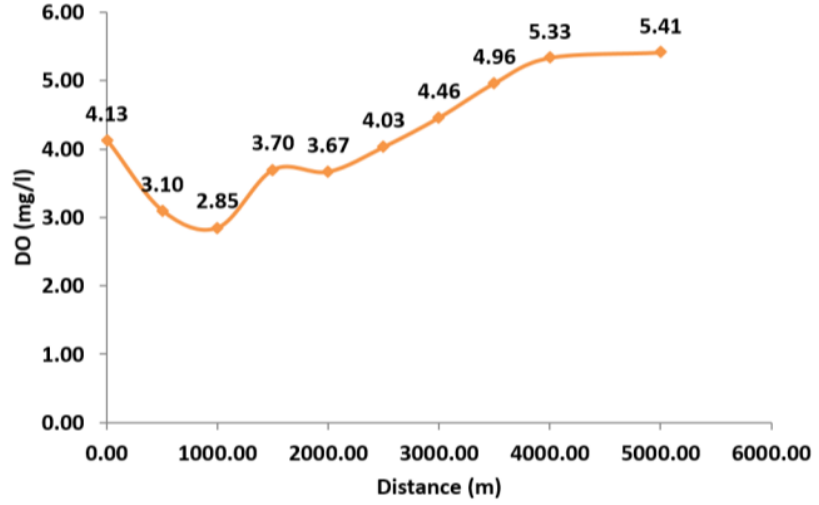

Figure 3.2: Spatial variation of Dissolved Oxygen concentration along Asoro stream

atmospheric condition may be responsible for this pattern of DO concentrations along the stream [5]. Regression analysis was applied to determine the relationship of the two variables (BOD and flow rate). In this study, the result of analysis showed that there was no significant relationship between time (weeks) and DO along Asoro stream regression analysis is used to get the linear regression of DO and time, and the equation is as follows:

$$
\mathrm{DO}=\mathrm{at}+\mathrm{b}
$$

where $D$ is the dissolved oxygen, $t$ is the time, and a and $b$ are variables (BOD and flow rate).

\section{CONCLUSION}

The temporal variation of dissolved oxygen concentration in Asoro stream was established which showed significant fluctuation of dissolved oxygen DO concentration between $3.38 \mathrm{mg} / \mathrm{l}$ at the first week (November) of sampling and $2.37 \mathrm{mg} / \mathrm{l}$ at 25th week (April) of sampling, while high level of DO concentration $(7.46 \mathrm{mg} / \mathrm{l}$ to $10.12 \mathrm{mg} / \mathrm{l})$ was recorded between 27 th week and 39th week of sampling (June and July) which showed high level of organic pollutant. Regression analysis showed that there was no significant relationship between time (weeks) and DO along Asoro stream.

\section{RECOMMENDATIONS}

Based on the findings of this research work, the following recommendations were made:

i. Adequate treatment of wastewater discharge from brewery industry should be ensured to meet standard limit set by FEPA and WHO.

ii Use of activated carbon could be included in the wastewater treatment facility for the of colour and odour which made the water unsuitable for domestic purpose. 


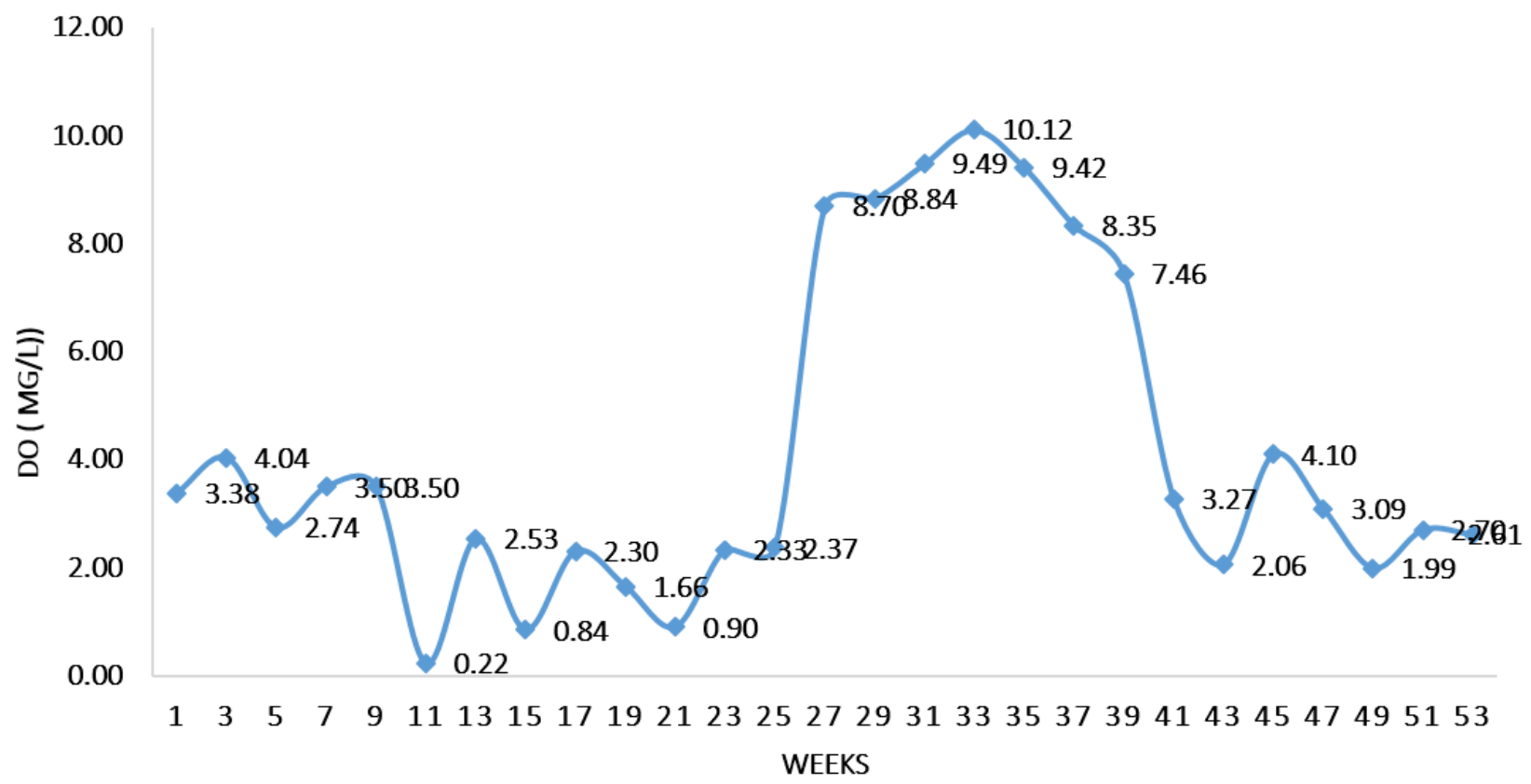

Figure 3.3 Temporal variation of Dissolved Oxygen (DO) concentration along Asoro stream

\section{REFERENCES}

[1] Hull, C.H.J., and De Filippi, J.A., The Prediction of Stream Reaeration rates: Civil Engineers Journal, 89 (2) pp. 97-109. 1963.

[2] Runkel R.Y. Evaluation of Relationships of Reaeration rate Coefficient for Modelling Dissolved Oxygen in a River with extreme flow Variations in Pakistan Hydrological Processes, 27 pp 949-963 2013.

[3] Wilcock, R.J. Study of River Re-aeration at different Flow Rates. Journal of Environmental Engineering, ASCE 114 (1) pp 24-45, 1988.

[4] Jeje. J.O., Ofoizie. I.E. and Achudume. A.CEffects of Industrial Effluents from a Brewery Industry on the Underground Water Quality of Ilesa in Osun State Nigeria; Proceedings of the $2^{\text {nd }}$ Annual Conference of the Institute of Ecology and Environmental Studies, 2:168-179. 2009. .

[5] Bellingham, K. Physicochemical Parameters of Natural Waters. Stevens Water Monitoring Systems, 2012.

[6] Krantz, F. Y. and Kifferstein, M.G. Development of water quality model in the Satilla River Estuary, Georgia. Ecological modelling. 178 (457) pp 482 - 465. 2004.

[7] Jeje, J.O. and Oladepo, K.T. Dissolved Oxygen Modeling: A case study of Asoro Stream in Ilesa,
Nigeria. Proceedings of The Nigerian Institution of Water Engineers - 2nd National Conference Abeokuta, 2: 23-32, 2018.

[8] Ademoroti C.M.A. Standard Methods for Water and Eluents Analysis, March Print and Consultancy 47 Jona Akpohoric Street, 13 DPA, Ugbowo Estate, Benin City, Edo State, Nigeria, pp 114 - 127 (1996).

[9] Raymond, P. A.; Zappa, C. J.; Butman, D.; Bott, T. L, and Potter, J. (2012) Scaling the gas transfer velocity and hydraulic geometry in streams and small rivers. Limnology and Oceanography. Fluids and Environments, 2 pp. 41-53.

[10] Von Sperling, M. Self-purification Ability of a Resurgence Stream. Chemosphere, 52 pp 17811795 (2014).

[11] Vannote, R. L.; Minshall, G. W.; Cummings, K. W.; Sedell, J. R.; Cushing, C. E.. The River continuum concept. Canadian Journal of Fisheries and Aquatic Sciences, 42 pp 160167,2015 .

[12] Duan, Z., James, M., Tang, Y.. "Modeling Oxygen Mass Transfer Rate through the Airwater Surface in Stratified Flows. World Environmental and Water Resources Congress, ASCE, Providence, RI, pp 371-408, 2010. 